\title{
Advanced Papillary Renal Cell Carcinoma
}

National Cancer Institute

\section{Source}

National Cancer Institute. Advanced Papillary Renal Cell Carcinoma. NCI Thesaurus. Code C162761.

A papillary renal cell carcinoma that has spread extensively to other anatomic sites or is no longer responding to treatment. 